Utah State University

DigitalCommons@USU

$5-1982$

\title{
Efficacy of Denning in Alleviating Coyote Depredations upon Domestic Sheep
}

James A. Till

Utah State University

Follow this and additional works at: https://digitalcommons.usu.edu/etd

Part of the Ecology and Evolutionary Biology Commons

\section{Recommended Citation}

Till, James A., "Efficacy of Denning in Alleviating Coyote Depredations upon Domestic Sheep" (1982). All Graduate Theses and Dissertations. 6423.

https://digitalcommons.usu.edu/etd/6423

This Thesis is brought to you for free and open access by the Graduate Studies at DigitalCommons@USU. It has been accepted for inclusion in All Graduate Theses and Dissertations by an authorized administrator of DigitalCommons@USU. For more information, please contact digitalcommons@usu.edu.




Efficacy of Denning in Alleviating Coyote

Depredations upon Domestic Sheep

by

James A. Till

and

Barrie Gilbert, Principal Investigator

Report to U.S. Department of Agriculture

under terms of contract 59-2491-02-112-0

Utah State University

Logan, Utah

1982 


\title{
EFFICACY OF DENNING IN ALLEVIATING COYOTE DEPREDATIONS UPON DOMESTIC SHEEP
}

\author{
by \\ James A. Ti11 \\ A thesis submitted in partial fulfillment \\ of the requirements for the degree \\ of \\ Master of Science \\ in \\ Wildlife Science
}

Approved :

Utah State University

Logan, Utah 


\section{ACKNOWLEDGEMENTS}

I would like to thank Fred Knowlton for his guidance, enduring patience and invaluable editorial assistance. Barrie Gilbert and Darwin Nielsen provided helpful comments and advice.

My sincere thanks are extended to trapper Vernon E. Dorn, who taught me a great deal about coyotes. He remains a tribute to the philosophy that a field worker should continually learn through careful observation and persistence, while remaining open-minded enough to change his mind.

Cooperation by Palm Livestock Company and Leo Sheep Company was greatly appreciated. I thank numerous sheepherders for their help and hospitality, gracias y vaya con Dios amigos.

My dear wife Susan is gratefully acknowledged for her support and continual understanding, as well as her ability to cope with un coyotero through long periods of separation.

Last, but by no means least, I feel it is necessary to acknowledge 2 tireless and underpaid "assistants", my dogs Slick and Linda. Without their efforts, this study would have been a great deal more difficult.

Partial funding for this study was provided by USDA Research Grant No. 59-2491-02-112-0. 
TABLE OF CONTENTS

Page



LIST OF TABLES ....................... . . . iv

LIST OF FIGURES . . . . . . . . . . . . . . . . . . v

ABSTRACT . . . . . . . . . . . . . . . . . vi

INTRODUCTION ..................... 1

METHODS .......................... 3

Study Area . . . . . . . . . . . . . . . . . 3



Cost-benefit Analysis ............... 5

RESULTS ........................ . 7

Biological Data .................... 13

Cost-effectiveness Analysis ............ 16

DISCUSSION . . . . . . . . . . . . . . . 20

Cost-benefit Analysis .............. . . 23

LITERATURE CITED . . . . . . . . . . . . . . . . 29






\section{LIST OF TABLES}

Table

Page

1. Numbers of depredation incidents, sheep killed and percent change in the 7 days before and after each of 5 coyote removal treatments, 1980 and 1981 ....... 8

2. Seven day predation sequences and numbers of sheep killed by day, pre and posttreatment periods, 1980 and 1981 ...................... 12

3. Relationships between depredations and various biological parameters (Pearson correlation coefficients) for removal treatments, 1980 and 1981 .................... 14

4. Animal remains found at dens, and stomach samples of offending adult coyotes, 1980 and $1981 \ldots$. . . . . . 17

5. Biological information from dens where 2 adults and their pups were removed, 1980 and 1981 . . . . . . . 33

6. Biological information from dens where only pups were removed, 1980 and 1981 ....................... 34

7. Biological information from offending adult coyotes, 1980 and 1981

8. Numbers of lambs killed and percent consumed by






\section{LIST OF FIGURES}

Figure

Page

1. Total kills observed pre and posttreatment,



2. Locations of known coyote dens on study area

in Carbon County, Wyoming, $1980(n=11)$ and




ABSTRACT

\title{
Efficacy of Denning in Alleviating Coyote Depredations upon Domestic Sheep
}

by

\author{
James A. Till, Master of Science \\ Utah State University, 1982
}

Major Professor: Frederick F. Knowlton

Department: Wildlife Science

Bands of domestic sheep lambing on the open range in south central Wyoming were monitored for predator losses prior to and following coyote (Canis Latrans) removals. Experimental treatments, including 1$)$ no removal (control), 2) removal of 2 adults and their pups, and 3) removal of pups only, were replicated 15 times each. Number of predation incidents (events) was reduced $98.2 \%$ by removing adults and pups. The number of sheep killed was reduced by $98.8 \%$. Removing only litters of pups resulted in a decrease of $87.7 \%$ in predation incidents, while total kills decreased $91.6 \%$. Overall, 23 of 30 predation sequences terminated immediately, while in all cases predation ceased within 3 days after renoving adult coyotes and/or their pups. In terms of "offending individuals", denning can be a very selective means of coyote depredation control. The data suggest 
that removing only litters of offending adults can be nearly as effective in stopping losses as removing the adults. Biological parameters such as litter size did not appear to influence kill frequencies. A cost-effectiveness analysis was calculated. 


\section{INTRODUCTION}

Depredations by coyotes (Canis latrans) upon domestic sheep result in greater losses of domestic livestock than any other predator-domestic prey interaction in the western United States (Balser 1974). Although several predator damage control techniques used to curtail or alleviate such losses have been subjectively ranked with regard to efficiency, selectivity and other factors (U.S. Fish and Wildlife Service 1978a), there is little quantitative data concerning the efficacy of any method. A critical response (Western Regional Coordinating Committee 1980) to a recent policy change on predator control (Andrus 1979) accentuates the need for objective evaluation of various coyote control methods. This study attempted to determine the efficacy of "denning", the practice of seeking out the dens of depredating coyotes and destroying the young and/or adults, in stopping depredations upon sheep.

Denning has been criticized for being "unselective" in terms of individual animals (Defenders of Wildlife 1978, Sierra Club 1978, The Humane Society 1978) and removal of individuals that obviously are not responsible for depredations. Other critics maintain that denning is solely a means of coyote population reduction (Gier 1968).

On the other hand, experienced predator control field personnel claim that denning can be a selective method for resolving specific depredation situations. Anderson (1969), 
among others, believes predation should cease when pups are found and destroyed. Royama (1970) stated that adult predators may attempt to maximize hunting efficiency while feeding young. This strategy may be used by coyotes provisioning pups. If so, removing pups and their attendant energy demands may reduce or eliminate depredations. Conceivably, predation upon domestic sheep by adult coyotes can be influenced by an indirect means, (i.e. removal of litters) as opposed to removal of the adults actually killing sheep. Absence of quantitative data leaves these questions unanswered.

The Cain Committee (1972) recommended cost-benefit analyses of predator control methods, stating such information was yet to be collected. Since most depredation control programs consist of several methods applied simultaneously, the effect in damage reduction and the measurement of prevented damage following application of a single control method is difficult to determine (U.S. Fish and Wildlife Service 1978a). However, because no other control methods were in effect during this study, except winter removal for fur, the opportunity was present to measure the cost and effectiveness of denning alone. 
METHODS

Study Area

Field work was conducted in south central Wyoming during Apri1, May and June of 1980 and 1981. Research efforts were concentrated in the eastern half of Carbon County, a major sheep producing area. The study area averages $2,000 \mathrm{~m}$ in elevation, with dorninant vegetation consisting of big sagebrush (Artemisia tridentata) and western wheatgrass (Agropyron smithii). Approximately 20,000 sheep are lambed on the open range with Basque and Mexican sheepherders in attendance. Spring lambing range is utilized until late June, when sheep are moved onto mountain summer range. Lambs are generally shipped in late September or 0ctober. Topography, vegetation, climate and sheep husbandry practices have been described by Tigner and Larson (1977).

Data Collection

In the course of norrial duties, sheepherders noted and reported sheep killed by coyotes. I did not assist in efforts to locate dead sheep, thereby assuring that monitoring intensity would be relatively constant throughout each trial. Consequently, numbers of sheep killed and reported must be considered minimal. Upon receiving a report of sheep killed by coyotes, I went to the area, examined all carcasses and conducted necropsies to verify the cause of death. Puncture wounds with 
attendant hemmorhaging were used as evidence of predation (Rowley 1970, Bowns 1976). To meet test conditions, a threshold of predation defined as 3 sheep killed in at least 2 incidents during 1 week was required. If this threshold was attained, and other predator control methods were not in effect (nor anticipated), the particular band of sheep was considered for study purposes.

Once test conditions were met, 1 of 3 treatments was instituted : (1) no coyote removal effected, to serve as a control; (2) removal of "offending" adult coyotes (individuals killing sheep) and their litter; and (3) removal of the complete litter but leaving the depredating adults. Each treatment was replicated 15 times. Each trial consisted of 3 distinct but consecutive phases: monitoring sheep losses during a pretreatment period, randomly choosing and applying 1 of the 3 treatments, usually taking a day to effect in case of treatments 2 or 3 , and finally, monitoring depredations for 7 days following completion of a treatment to conclude each trial. Several incomplete treatments (removal of 1 adult and pups, or removal of adults only) also occurred in 1980.

Efficacy was assessed on the basis of changes in both the number of depredation incidents and the number of sheep killed in the week after treatment compared to the week preceeding. Kruskall-Wallis, Wilcoxson Signed Rank and Wilcoxson Rank Sum tests were used to compare number of incidents, number of kills 
and cranges in each as a result of treatments.

Coyote dens were located by tracking adult coyotes away from sheep kills (Young and Dobyns 1945). Pups were destroyed in the dens with a fumigant described by Tigner and Larson (U.S. Fish and Wildlife Service 1978b). Adult coyotes were shot at or near the den sites when the treatment required. In no-removal trials (controls), dens were not approached or disturbed.

Biological data was recorded on coyotes collected during the study in an attempt to relate various biological parameters to depredation frequencies. Den sites were plotted on a map for density determination as well as den locations in relation to depredation areas. Following fumigation, dens were excavated and pups were counted and weighed. Age was estimated by tooth eruption patterns (Bekoff and Jameison 1975). A thorough search was made of the den area for animal remains. Adult coyotes were weighed with a spring balance and age assessed by means of tooth wear (Gier 1968). Adult stomach samples were analysed in the field by ocular estimate.

Cost-benefit Analysis

A generalized cost-effectiveness analysis was calculated based on field seasons combined. Assumptions for this analysis were :

1) The monitoring intensity did not change during pre and posttreatment periods. Therefore, the proportion of sheep actual y killed by coyotes that were located is probably the same 
pre and posttreatment.

2) The number of sheep killed pretreatment in the removal treatments accurately reflects the number that would have been killed had treatments not been applied. This assumption is supported by the kills documented in the control treatment.

3) The wages, expenses and field time of personnel are reasonable for this region.

4) The number of sheep saved does not necessarily represent the absolute number that would be sold as 100 ib fat lambs in the fall. Low over-summer mortality is expected; however, I feel that this level of mortality is insignificant compared to the number of lambs killed by coyotes and not located during the experiment. In addition, all surviving lambs will not weigh 100 lbs at shipping, and depending on various factors, a certain proportion of ewe lambs will be kept as replacements. I feel it is reasonable to use these conservative loss figures as a baseline for calculating at what point a denning program may become cost-effective. 
RESULTS

During the 2 field seasons, 55 individual trials were documented (Table 1). There were 15 in each of the 3 treatments, plus 10 trials from incomplete treatments.

Predation patterns varied considerably among trials, but the no removal (control) treatment tested the validity of the test procedure of comparing kill rates in the pretreatment and posttreatment periods. A change in number of sheep killed provides 1 measure of treatment efficacy. Number of kills may be influenced by a variety of factors, whereas the number of predation incidents (events) is probably more closely related to depredation behavior (or lack thereof) exhibited by coyotes. In the no removal (control) treatment, the change from pre to posttreatment was $-4.2 \%$ for both incidents and kills. No difference $(T=9, n=6, \quad p<0.05)$ could be detected between the number of incidents pre and posttreatment. Number of kills observed pretreatment was not different $(T=34, n=12, p<0.01)$ than number of kills observed posttreatment. In addition, no differences $\left(X^{2}=6.8877, d f=3, p<0.05\right)$ could be shown in total incidents, or in total kills $\left(x^{2}=2.5538, d f=3, p<0.05\right)$ between pre and posttreatment periods of the no removal (control) treatment and pretreatment periods of the removal treatments (Figure 1). 
Page 8

Table 1. Numbers of depredation incidents, sheep killed and percent change in the 7 days before and after each of 5 coyote removal treatments, 1980 and 1981.



Number of Sheep xilled

\begin{tabular}{|c|c|c|c|c|c|c|c|c|}
\hline \multirow[b]{2}{*}{ Irea tment } & \multirow[b]{2}{*}{$\underline{N}$} & \multicolumn{3}{|c|}{ Pretreatment period. } & \multicolumn{3}{|c|}{ Posttreatment period } & \multirow{2}{*}{$\begin{array}{l}\text { percent } \\
\text { decrease }\end{array}$} \\
\hline & & total & $\overline{\underline{x}} \pm$ S.D. & range & total & $\underline{\bar{x}} \pm$ S.0. & range & \\
\hline $\begin{array}{l}\text { No coyotes removed } \\
\text { (control) }\end{array}$ & 15 & 72 & $4.8 \pm 1.6$ & $2-7$ & 69 & $4.6 \pm 2.1$ & $2-9$ & 4.2 \\
\hline Renove pups and 2 adults & 15 & 80 & $5.3 \pm 2.2$ & $3-9$ & 1 & $0.1 \pm 0.3$ & $0-1$ & 98.8 \\
\hline Remove pups and 1 adult & 5 & 13 & $2.6 \pm 0.9$ & $2-4$ & 2 & $0.4 \pm 0.6$ & $0-1$ & 84.6 \\
\hline Remove 2 adults only & 5 & 28 & $5.6: 2.3$ & $3-8$ & 0 & 0 & 0 & 100.0 \\
\hline Remove pups only & 15 & 83 & $5.5 \pm 1.6$ & $3-9$ & 7 & $0.5 \pm 0.5$ & $0-1$ & 91.6 \\
\hline $\begin{array}{l}\text { Totals } \\
\text { (removal treatments) }\end{array}$ & 40 & 204 & $5.1 \div 2.0$ & $2-9$ & 10 & $0.3 \pm 0.4$ & $0-1$ & 95.1 \\
\hline
\end{tabular}






Figure 1. Total kills observed pre and posttreatment, 1980 and 1981. 
Numbers of pretreatment incidents among all treatments were similar $(T=37, n=12, p<0.01)$, as were the numbers of kills observed $(T=35.5, n=12, p<0.01)$. Since removal treatments were initially similar, one might expect similar results following treatment application.

In trials where adults and pups were removed, the number of posttreatment depredation incidents was reduced $98.2 \%$ from pretreatment levels (Table 1). The number of posttreatment indidents $(\bar{x}=0.1)$ was different $(z=4.9804, p<0.001)$ than the number of pretreatment incidents $(\bar{x}=3.7)$. Following removal of adults and pups, the number of kills observed declined $98.8 \%$. The number of posttreatment kills $(\bar{x}=0.1)$ was different $(z=4.9336, p<0.001)$ from number of kills observed pretreatment $(\bar{x}=5.3)$. In the 15 trials, only 1 kill was recorded following removal of adults and pups. In this case, 9 lambs were killed in the pretreatment period, and 1 lamb was killed the day after the presumed offending pair and their pups were removed.

Since denning per se is usually considered a process of removing only pups (U.S. Fish and Wildlife Service 1978a), and since adilt coyotes are often difficult to capture, even at den sites, an important aspect of this study was to determine if removing litters of pups only would influence the killing behavior of their parents. Depredation incidents were reduced $87.7 \%$ following removal of pups only (Table 1). Among the 15 trials, the number of posttreatment indidents $(\bar{x}=0.5)$ differed 
significantly $(z=4.8102, p<0.001)$ from the number of pretreatment incidents $(\bar{x}=3.8)$ and the number of kills observed pretreatment $(\bar{x}=5.5)$ was reduced $91.6 \%$ and was significantly different $(z=4.7544, p<0.001)$ than the number of posttreatment kills $(\bar{x}=0.5)$ in trials where only litters were removed.

In 8 of 15 trials (53.3\%), killing stopped immediately solely upon the removal of the pups of offending adults. In the other 7 trials $(46.7 \%), 1$ additional depredation occurred during the first 3 days after removal of litters (Table 2). No depredations were reported during days 4 through 7 posttreatment.

In comparing removal treatments, the most meaningful behavioral statistic probably is the change in the number of incidents pre to posttreatment (i.e. number of incidents posttreatment minus number of incidents pretreatment). There was no difference $(z=0.5702, p<0.001)$ between the change in the number of predation incidents occurring before and after treatment in the 2 types of treatments where coyotes were removed.

Collectively, treatments involving removal of adult coyotes and/or their pups were documented in 40 trials. In 31 of the 40 trials $(78 \%)$, killing was stopped immediately, while depredations were terminated in all cases 3 days following treatment. 
Page 12

Table 2. Seven day predation sequences and numbers of sheep killed by day, ere and post treatment periods, 1980 and 1981.




Biological Data

Multiple and simple linear regression revealed few significant relationships between depredation frequencies and several biological parameters (Table 3). Litter size, age of pups and the distance between kill sites and the den appeared to have little influence upon the total number of sheep killed, or the rate at which they were killed.

The densities of dens (Figure 2) where adults and/or pups were removed ranged from 1 den/117.1 $\mathrm{km}^{2}$ in $1980(\mathrm{n}=11)$ to 1 den/110.4 $\mathrm{km}^{2}$ in $1981 \quad(\mathrm{n}=19)$. These figures must be evaluated carefully. There were 15 dens (9 in 1980 and 6 in 1981) of depredating coyotes that served as controls. The locations of these dens were suspected, though not verified, so they do not enter into density calculations. In addition, evidence suggested other dens (i.e. of non-offending adults) in the study area. I suspect double these densities would still be conservative. In any case, these densities are substantially higher than those reported by Young and Jackson (1951). The average distance from the site of depredations to the den was $3.25 \mathrm{~km}$, with a range of $<1 \mathrm{~km}$ to $10 \mathrm{~km}$. 
Table 3. Relationships between depredations and various biological parameters (Pearson correlation coefficients) for removal treatments, 1980 and 1981.

\begin{tabular}{|c|c|c|c|c|c|}
\hline & \multicolumn{5}{|c|}{ Pups \& Adults $(n=15)$} \\
\hline & Female age & Pup age & Littersize & Distance & Incidents \\
\hline Kills & 0.121 & 0.002 & 0.173 & -0.089 & $0.837^{a}$ \\
\hline Incidents & 0.054 & 0.007 & 0.069 & -0.112 & \\
\hline Rate & 0.169 & -0.032 & 0.241 & 0.013 & \\
\hline Distance & $-0.01 \varepsilon$ & 0.326 & -0.301 & & \\
\hline Littersize & 0.152 & -0.023 & & & \\
\hline
\end{tabular}

Pup aģe

0.185

Kills

Pun age

Pups only $(n=15)$

0.105

Littersize

Distance

Incidents

Incidents

$-0.197$

$-0.101$

$0.589^{b}$

$0.439^{b}$

Rate

0.300

0.129

$0.352^{c}$

vistance

0.221

$-0.263$

0.244

Littersize

0.079

kills

Pup age

All data $(n=30)$

0.042
Littersiz

Distance

Incidents

$0.073 \quad 0.159 \quad 0.688^{\mathrm{a}}$

Incidents

$-0.094$

0.086

0.068

Rate

0.146

0.009

0.125

Distance

0.263

$-0.032$

Littersize

0.029 


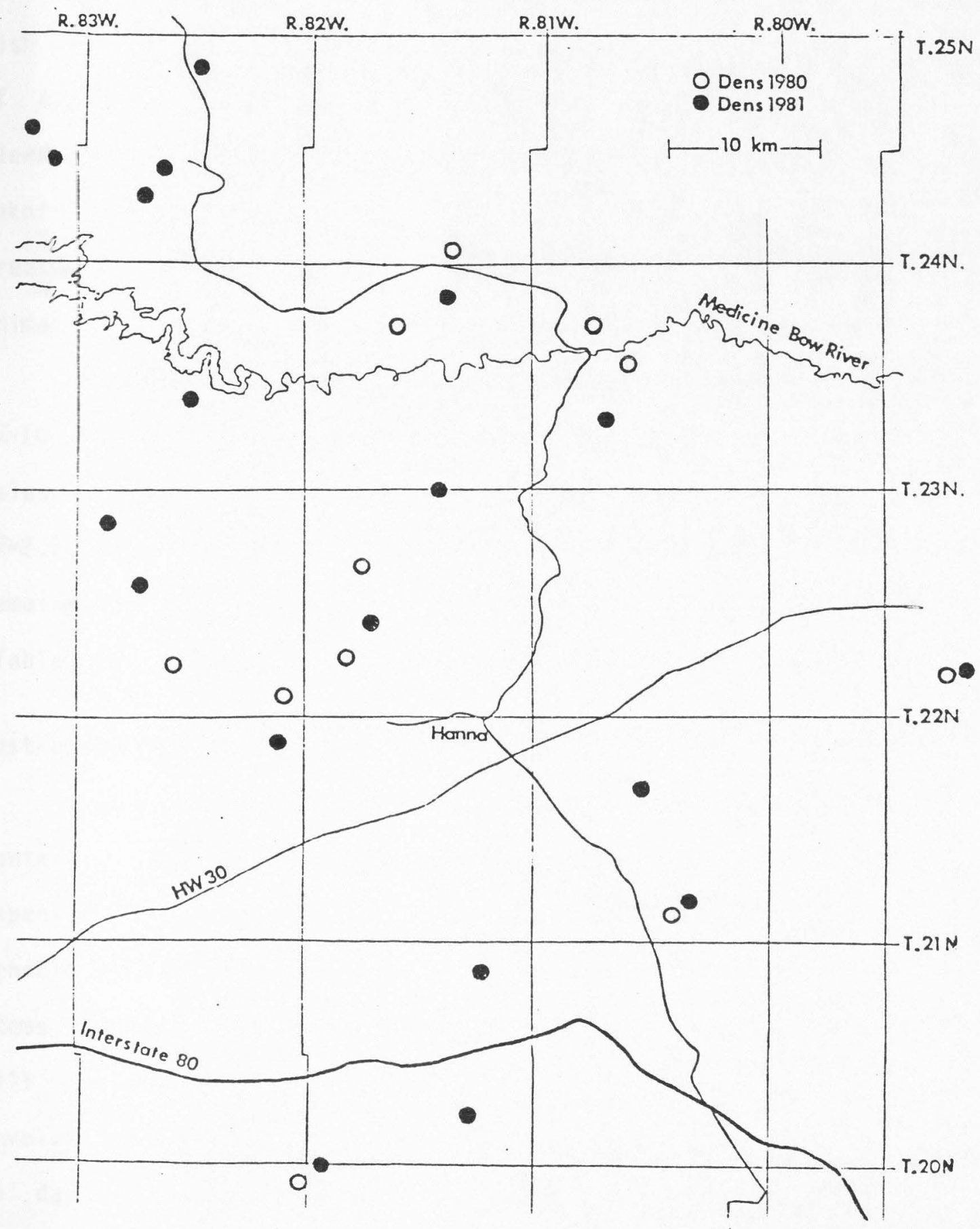

Figure 2. Locations of known coyote dens on study area in Carbon County, Wyoming, $1980(n=11)$ and $1981 \quad(n=19)$. 
Litter size $(\bar{x}=6.3$, range 4-11) was similar to that reported by Young and Dobyns (1945), Hamlett (1938) and U.S. Fish and Wildlife Service (1978a). Pups at approximately 2 weeks of age averaged $0.91 \mathrm{~kg}$, which is similar to weights reported by Gier (1968), and higher than those reported by Hallett (1977) and Bekoff and Jamieson (1975). The age of pups removed during treatments averaged 26 days, with a range of 2 to 49 days. Animal remains were found at $77 \%$ of the dens examined (Table 4 ). Adult coyote weights ranged from $9.1 \mathrm{~kg}$ to $12.7 \mathrm{~kg}$ $(\bar{x}=10.9)$ among females, and $11.4 \mathrm{~kg}$ to $18.2 \mathrm{~kg}(\bar{x}=13.6)$ among males. Tooth wear estimates of age suggested ranges of 1-6 years $(\bar{x}=2.9)$ for females and $2-6$ years $(\bar{x}=3.7)$ for males. Sheep remains were found in 9 of $31(29 \%)$ of adult stomach samples (Table 4).

Cost-effectiveness Analysis

The average salary for a USDI (Animal Damage Control) den hunter in Wyoming is $\$ 1020.00 /$ month, with $\$ 650.00 /$ month in expenses ( $F$. Christensen 1982 pers.comm.). Expenses include vehicle maintenance and gasoline, per diem and miscellaneous items such as horse rental. Therefore, a cost of $\$ 1670.00 /$ month will be used in this analysis. Field personnel are generally involved in den hunting from 15 April until 1 July $(2.5$ months or 75 days). Total expenses are calculated as : $\$ 1670.00 \times 2.5$ months $\times 2$ years $=\$ 8350.00$. 
Table 4. Animal remains found at dens, and stomach samples of offending adult coyotes, 1980 and 1981 .

Animal remains at or near den $(n=30)$

Sheep or lamb №. $\%^{*}$

Cottontail rabbit

$8 \quad 27$

Sage grouse

$8 \quad 27$

Sheep carrion

$4 \quad 13$

Misc. carrion

$3 \quad 10$

Jackrabbit

$3 \quad 10$

Misc. birds

27

Misc. rodents

27

Adult coyote skin

13

13

\section{Adult stomach contents $(n=31)$}

\begin{tabular}{lcr}
\hline & No. & $\%^{\star}$ \\
\cline { 2 - 3 } Sheep or lamb & 9 & 29 \\
Cottontail rabbit & 3 & 10 \\
Sage grouse & 1 & 3 \\
Misc. carrion & 1 & 3 \\
Jackrabbit & 1 & 3 \\
Misc. rodents & 6 & 19 \\
Empty & 2 & 6 \\
Grass & 1 & 3
\end{tabular}

* Frequency occurrence 
During the 2 field seasons, 40 dens of depredating coyotes were located and rernoved in approximately 5 months field time over 2 seasons for an average of 0.27 dens/day, or roughly 2 dens/week (assuming den hunting is conducted on weekends).

Lamb prices fluctuate depending on market conditions and other factors. The lamb market in 1981 was severely depressed. Therefore, a 5-year (1977-1981) average probably represents a more realistic and accurate price for lambs. Exact prices are variable, but it seems reasonable to use the 5-year average of $\$ 57.74 /$ cwt for fat lambs marketed in 0ctober as the average value of lambs lost to coyotes. This of course assumes that coyote-killed lambs would survive to shipping; however, as acknowledged in assumption (4), this possible overestimation of values is probably outweighed by other factors. Given that a value of $\$ 57.74 / 1 \mathrm{amb}$ is reasonable, and that total expenses incurred amount to $\$ 8350.00$, the following formulae should estimate when the program becomes cost-effective. The average expense to locate and remove 1 den of offending coyotes was $\$ 8350.00 / 40=\$ 208.75$. This average divided by the average value of 1 lamb should estimate the number of lambs it would be necessary to save to recover costs (on a per den basis) : $208.75 / 57.75=3.62$ lambs. The average number of lambs killed per week is calculated as the total number of kills observed in the pre and post control treatment, plus all pretreatment kills observed in removal treatments, divided by the number of "den 
weeks" (i.e. 7 day predation sequences attributable to 1 den), or $345 / 70=4.93$. I am assuming that an average of 4.93 lambs would be killed in an average 7 day period by adults to feed pups from 1 den. The determination of a time period when costs are recovered is calculated by dividing the average number of lambs required to break even (3.62) by the average number of 1 ambs killed/week (4.93), which equals 0.73 weeks. Provided these rates of predation and den removal are reasonable, only $(0.73)(7)$ $=5.1$ days are necessary to recover costs. 


\section{DISCUSSION}

It is possible that adult coyotes initiate and continue depredations upon domestic sheep during the pup-rearing season as a means of maximizing their hunting efficiency. Royama (1970) implied that one way in which predators may do this is to feed young more "profitable" prey items than they consume themselves. Domestic lambs are possibly the most "profitable" prey items availabie to coyotes at this time of the year, since they are abundant, easily preyed upon and larger than most naturel prey. Additional credence to the hypothesis that coyotes select for "profitable" prey when feeding a litter of pups may be gained by considering the relatively great distances adult coyotes will travel to obtain domestic lambs (Young and Jackson 1951, Lemm 1973), when less "profitable" (i.e. smaller, less abundant and more difficult to capture) prey items are found nearer the den. When pups and their attendant energy demands are eliminated, it is no longer necessary for adults to maximize hunting efficiency, and depredations upon lambs should be less essential.

These data indicate that the predation behavior displayed by coyotes upon domestic sheep can be significantly altered by removing only litters of pups. Although depredations sometimes continued for 1 to 3 days following pup removal, the eventual result (no killing) was similar to that of trials where coyotes actually responsible for killing sheep were removed. Possibly the unexpected behavioral shift encountered by adults accustomed 
to provisioning pups necessitates this adjustment period. The immediate cessation of killing in 14 of 15 trials indicates that removing offending adults and their pups can be very effective in stopping depredations. Removing only litters appears to provide nearly the same degree of effectiveness regarding the alleviation of depredations, which demonstrates the selectivity and effectiveness of such coyote removal treatments.

Additional adult coyotes are commonly found caring for pups (Ryden 1975, Camenzind 1978, Bowen 1982). The occurrance of more than 2 adults at a den has frequently been noted by field personnel. Possibly an "extra" adult was responsible for the 1 posttreatment kill noted after removing 2 adults plus pups in 1 trial. Extra adults were observed at $6(40 \%)$ of the dens where adults were removed. Since there were no apparent differences in kill rates between dens with or dens without "extras", the presence of additional adult coyotes was considered negligible.

Learned predatory behavior is another factor which influences depredations by coyotes on spring lambing ranges. The extent to which this factor governs total losses is speculative, since all adult coyotes raising litters in lambing areas do not kill lambs. The predilection of some coyotes for lambs encompasses more than a simplified model pertaining to a maximization of the available prey resource.

Predation frequencies (for pre and post control, and pre removal treatments) are similar to those reported by field 
personnel and damage assessment studies. Perhaps more intensive monitoring of losses would account for more sheep carcasses; whether relationships to information such as litter size and pup age would change is not known. No general biological patterns emerged regarding the tendency of certain coyotes to kill sheep for the purpose of feeding pups.

Information pertaining to spring coyote densities on lambing ranges is not extensive. During this study, the density of depredating coyotes' dens averaged at least 1 den $/ 70 \mathrm{~km}^{2}$, with 1 area of $<80 \mathrm{~km}^{2}$ containing 5 dens in 1981 . Whether the ready availability of large numbers of domestic lambs resulted in a high density of coyote dens is conjectural. It must be emphasized that these densities are minimal spring den densities of depredating coyotes; total coyote density was not estimated.

From these data, it would be difficult to "profile" an offending adult coyote with any assurance that it would differ morphologically from a coyote living in the area but not killing sheep. Adult weights and ages appear to be well within population ranges. Three crippled (peg-leg) coyotes were observed as offending adults. However, the data do not indicate that these coyotes were behaviorally different (as suggested by Sperry 1939) regarding depredations upon sheep.

Some evidence of non man-related coyote mortality was encountered during each field season. An extremely white-furred pup was found dead $1 \mathrm{~km}$ from a den containing 7 healthy siblings 
(Trial 102). A necropsy of the dead pup showed no physical damage or aberration. Camenzind (1978) suspected the destruction of pups by adult coyotes from neighboring territories. I did not observe this phenomena; however, control personnel have reported remains of dead coyote pups at dens. Intra-litter strife may result in coyote pup mortality (Hallet 1977), and it is possible that an unmeasured amount of mortality among coyote pups occurred during this study. At one den (Trial 112), a $5 \times 4 \mathrm{~cm}$ piece of fresh adult coyote skin was found. Both adults collected nere appeared normal. The extent of "natural" mortality and its importance in this area is unknown.

Cost-benefit Analysis

Most predator losses occurred prior to docking, when the first accurate count of range-born lambs is made. Since it is virtually impossible to account for all lambs born on the range (Tigner and Larson 1977), the percent of each bands' lamb crop lost to coyotes was not estimated; only confirmed coyote kills documented prior to and following each trial enter into calculations. Damage assessment workers (Bowns 1976, Nass 1977 ) concurred on the difficulty in locating all mortalities. Klebenow and McAdoo (1976) stated that were it not for their efforts in monitoring losses, sheepherders would have found less than half of the losses that occured. One author (Nesse 1973) felt that actual predator losses were 1.5 times as numerous as those located. Another possible source of error in calculations 
of total losses is related to the propensity of some coyotes to carry pieces of food items to the den. Consequently, additional depredations may have occurred that were not documented. Adjustments for such inaccuracies were not made. The loss figures must be assumed minimal; total predator losses must be somewhat greater.

The cost-effectiveness analysis calculated here is short-term, essentially relating the immediate benefits of removing offending adults and/or their pups in particular predation situations. One could speculate that the duration of these predation sequences would continue relatively unabated unless the sheep were moved. The energy demands of a litter of pups may force some coyotes to turn to livestock as a source of food (Boggess et.al. 1980). Since sheep remain for at least another month on the study area prior to trailing to the summer range, the total losses inflicted by a pair of coyotes provisioning pups could be severe if control measures were not implemented. Although lamb losses to coyotes are generally highest in the spring, another major predation period during the late summer or early fall has been noted (Klebenow and McAdoo 1976, Tigner and Larson 1977, Boggess et.al. 1980). Boggess et.al. (1980) and others suggest that adult coyotes may turn to an easily obtainable food source to meet nutritional demands of pups at this time of the year. Field personnel assert that this increase is related to learning and developement of sheep-killing 
behavior in pups. Most southern Wyoming sheep are pastured for a short period on or near the lambing ranges following transhumance. Lamb losses to coyotes just prior to shipping are most damaging financially since the cost of production is nearly complete, while returns have yet to be realized. The depredation reduction gained by removing a pair of offending coyotes and/or their pups from certain areas is potentially many times greater than that observed immediately after apprehending the proper individual coyotes, although it is yet uncertain whether adults lacking pups will initiate depredations in the fall. Long-term data sets of predation sequences under these circumstances are non-existant.

Other possible assumptions which warrant consideration include husbandry practices and experience of control personnel. This analysis assumes that sheepherders tend bands of sheep lambing on the open range. It assumes that they are relatively cooperative, since the greatest benefit in depredation reduction can be gained when control measures are instituted as soon as possible after killing begins. Bands of sheep not under supervision may sustain heavy predator losses before control can be initiated. Another important factor in this analysis is the experience of the control personnel. As Young and Dobyns (1945) state, "the most important qualifications of a den hunter are keen observation, persistence, and familiarity with the habits of coyotes." These data indicate that denning is cost-effective 
under conditions encountered in the study. Den hunting was conducted by an experienced trapper who was familar with the study area. He was assisted by dogs trained to locate dens and adult coyotes. Depredation rates observed in this research are not extraordinary; therefore, the major factor influencing the short period required to recover costs is possibly the experience of the den hunter. To assume that denning is cost-effective in all conditions probably is inappropriate.

Wagner (1972) states that some data suggest depredations are reduced following generalized coyote population reduction. However, he continues "the evidence on total sheep losses shows little, if any, correlation with coyote population density, and the use of control measures which reduce that density." Denning is considered by some (including Gier 1968) to be a means of coyote population reduction, though others doubt this (U.S. Fish and Wildlife Service 1978a). When considering relatively small areas such as lambing ranges, however, it is possible that pup removal may effect a temporary population reduction. Importantly here is the concept that the proximate factor behind depredations may be diminished. If a population reduction through denning of offending family groups extends past normal lamb shipping dates, a fall predation peak may not occur. The effect of such reduced densities on the more mobile part of adjacent coyote populations has not been measured, but removing only pups may reduce fall depredations significantly. 
Since this research indicates that depredations upon domestic sheep can be alleviated by removing litters from offending adult coyotes, one might wonder about situations where no pups are born. Coyotes are territorial around a den (Camenzind 1978, Bowen 1982); whether they remain so if pups are removed or if the female fails to conceive after a pair bond is formed and a territory established is not known. Theoretically, without pups, depredations caused by coyotes should be minimal during the spring. If coyotes lacking pups will still defend a territory to the exclusion of others, it is interesting to speculate about the efficacy of controlling depredations on areas of chronic depredations, such as lambing ranges, by sterilization of resident adult coyotes.

The contention that it is better not to remove non-offending coyotes from livestock areas rather than have them replaced by other coyotes that may or may not cause problems has been mentioned by some coyote management biologists (Boggess et.al. 1980). As demonstrated by this study, the status of offending adults can be changed by removing their pups in the spring. The permanency of that new status is a question for further research.

The scope of the predator-prey interaction between coyotes and domestic sheep is beyond this paper; however, it appears that when dealing with depredating coyotes on lambing ranges, the evidence is persuasive that regardless of prior experience or 
other factors on the part of the "offenders", attempts to maximizing hunting efficiency potentially lead to sheep losses. Importantly, this effect can be reversed through selective pup removal. If these maximization attempts are indeed the cause that leads to the well documented effect in sheep 1osses, an important and selective preventative control method might be gained by manipulating the mechanism (cause) which triggers depredations. Extensive studies might determine if a long-term behavioral change can be effected. This research has documented the results of manipulation after the fact, further research should probe the efficacy of selectively preventing depredations. Future research may provide alternatives to denning in resolving coyote depredations, recognizing the need for both livestock protection and the aesthetic and economic value of coyotes. 


\section{LITERATURE CITED}

Anderson, T.E. 1969. Identifying, evaluating and controlling wildlife damage. Pages 497-521in R.H. Giles,ed. Wildlife Management Techniques, 3rd.ed. The Wildlife Society, Washington, D.C. 633pp.

Andrus, C.D. 1979. Memorandum to Assistant Secretary for Fish, Wildlife and Parks. November 8, 1979.

Balser, D.S. 1974. An overview of predator-livestock problems with emphasis on livestock losses. Trans. North Am. Wildl. and Nat. Resour. Conf. 39:292-300.

Bekoff, M. and R. Jamieson. 1975. Physical developement in coyotes (Canis latrans), with a comparison to other canids. J. Mamma1. 56:685- $6 \overline{92 .}$

Boggess, E.K., F.R. Henderson, and C.E. Spaeth. 1980. Managing Predator Problems:practices and procedures for preventing and reducing livestock losses. Kansas St. Univ. Coop. Ext. Serv. $19 \mathrm{pp}$.

Bowen, W.D. 1982. Home range and spatial organization of coyotes in Jasper National Park, A.lberta. J.Wild . Manage. $46(1): 201-215$.

Bowns, J.E. 1976. Field criteria for predator damage assessment. Utah Sci. 37:26-30.

Cain, S.A., J.A. Kadlec, D.L. Allen, R.A. Cooley, M.B. Hornocker, A.S. Leopold and F.S. Wagner. 1972. Predator Control: a report to the Council on Environmental Quality and Department of the Interior. Univ. Mich. Press. $207 \mathrm{pp.}$

Camenzind, F.J. 1978. Behavioral ecology of coyotes in the National Elk Refuge, Jackson, Wyoming. Pages 267-296 in M. Bekoff,ed. Coyotes:biology, behavior and management. Academic Press, New York, N.Y.

Defenders of Wildlife. 1978. public comment U.S. Fish and Wildi ife Service's Mammalian Predator Damage Management for Livestock Protection in the Western United States, Final EIS:443-465.

Gier, H.T. 1968. Coyotes in Kansas. Kansas State Univ. Agric. Exp. Sta. Bu11. 393. 118pp.

Hallet, D.L. 1977. Post-natal mortality, movements, and den sites 
of Missouri coyotes. M.S. Thesis. Univ. Missouri, Columbia. $144 \mathrm{pp}$.

Hamlett, G.W.D. 1938. The reproductive cycle of the coyote. U.S. Dept. Agr. Tech. Bu11. 616. 11pp.

Humane Society. 1978. public comment U.S. Fish and Wildi ife Service's Mammalian Predator Damage Management for Livestock Protection in the Western United States, Final EIS:404-407.

Klebenow, D.A. and K. MCAdoo. 1976. Predation on domestic sheep in northeastern Nevada. J. Range Manage. 29(2):96-100.

Lemm, W.C. 1973. Coyote denning as a method of damage control. Proc. Great Plains Wildl. Damage Contr. Workshop. p 39-44.

Nass, R.D. 1977. Mortality associated with sheep operations in Idaho. J. Range Manage. 30(4):253-258.

Nesse, G.E. 1973. Predation and the sheep industry in Gienn County, California. M.S. Thesis. Univ. Calif., Davis. 127pp.

Rowley, I. 1970. Lamb predation in Australia: incidence, predisposing conditions, and the identification of wounds. CSIRO Wild1. Res. 15: 79-123.

Royama, T. 1970. Factors governing the hunting behavior and selection of food by the great tit (Parus major). J. Anim. Ecol. 39(3): 619-669.

Ryden, H. 1975. God's Dog. The Viking Press. N.Y. 315pp.

Sierra Club. 1978. public comment U.S. Fish and Wildlife Service's Mammalian Predator Damage Management for Livestock Protection in the Western United States, Final EIS:408-411.

Sperry, C.C. 1939. Food habits of peg-leg coyotes. J. Mammal. 20: $190-194$.

Tigner, J.R. and G.E. Larson. 1977. Sheep losses on selected ranches in southern Wyoming. J. Range Manage. 30(4):244-252.

U.S. Fish and Wildilife Service. 1978a. Predator Damage in the West: a study of coyote management alternatives. U.S. Dept. Inter. Washington, D.C. 168pp.

U.S. Fish and Wildlife Service. 1978b. Newly developed gas cartridge effective as a coyote den fumigant. Denver Wildlife Research Center. 3pp (mimeo). 
Wagner, F.H. 1972. Coyotes and sheep. 44th Faculty Honor Lecture. Utah State Univ., Logan. 59pp.

Western Regional Coordinating Committee, WRCC-26. 1980. Predation on Domestic Animals, a response to Secretary of Interior Andrus' policy statement pertaining to the Animal Damage Control Program. Utah Agr. Exp. Sta., Utah State Univ., Logan. 91pp.

Young, S.P. and H.W. Dobyns. 1945. Coyote control by means of den hunting. U.S. Dept. Int., Fish and Wildlife Circ. 7. $8 \mathrm{pp}$.

Young, S.P. and H.H.T. Jackson. 1951. The Clever Coyote. The Stackpole Company, Harrisburg, Penn. 411pp. 
Page 32

APPENDIX 
Table 5. Biological information from dens where 2 adults and their pups were removed, 1980 and 1981.

\begin{tabular}{|c|c|c|c|c|c|c|c|c|}
\hline Trial & 1 Date & Topography & $\begin{array}{l}\text { Distance } \\
(\mathrm{km})\end{array}$ & Animal Remains & No. Pups & $\begin{array}{l}\text { Est. } \\
\text { Age }\end{array}$ & Exposure & Notes \\
\hline 101 & $4-25-80$ & cutbank wash & 1.6 & *sheep & 7 & 3 & w & \\
\hline 102 & $5-16-80$ & rolling sagehills & 3.2 & $\begin{array}{l}\text { grouse, cottontail } \\
\text { lambskin }\end{array}$ & 8 & 42 & S & $\begin{array}{l}\text { Dead pup found } 1 / 2 \\
\text { mile away }\end{array}$ \\
\hline 103 & $5-17-80$ & rocky slope & 3.2 & cottontail fur\&feet & 5 & 28 & s & \\
\hline 104 & $5-29-80$ & alkali sink & 2.4 & cottontail fur & $y$ & 35 & N & \\
\hline 105 & $5-29-80$ & rocky canyon & 0.8 & $\begin{array}{l}\text { sage grouse, *deer, } \\
\text { "sheep leg }\end{array}$ & 6 & 28 & S & \\
\hline 106 & $6-09-80$ & gunibo badlands & 9.7 & cottontail fur & 4 & 28 & $s$ & \\
\hline 107 & $6-14-80$ & rimrocks & 1.6 & $\begin{array}{l}\text { antelope fawn, cottontail, } \\
\text { lamb skin and bones }\end{array}$ & , 4 & 28 & w & Wool in pup scats \\
\hline 108 & $6-24-80$ & rimrocks & 6.4 & lamb leg bones & 7 & 42 & $\mathrm{~s}$ & Pups born $1 / 2$ mile $W$ \\
\hline 109 & $4-23-81$ & rocky canyon & 1.6 & cottontail fur & 10 & 21 & E & \\
\hline 110 & $5-04-81$ & rolling sagehills & 1.6 & *antelope carcass & 7 & 7 & E & $6 \$, 1 \rightleftharpoons$ pup \\
\hline 111 & $5-09-81$ & rocky draw & 1.6 & $-\quad-$ & 5 & 14 & N & Pups born $1 / 4$ mile $E$ \\
\hline 112 & $5-12-81$ & rocky slope & 3.2 & $\begin{array}{l}\text { lamb lungs\&skin, fresh } \\
\text { adult coyote skin }\end{array}$ & 6 & 28 & E & \\
\hline 113 & $5-14-81$ & rocky draw & 4.8 & cottontail fur, *deer & 6 & 28 & N & \\
\hline 114 & $5-20-81$ & tall sage cutbank & 3.2 & cottontail fur & 7 & 35 & N & Pups born I mile SH \\
\hline 115 & $5-29-81$ & rocky slope & 1.6 & marmot, lambskin & 6 & 42 & E & \\
\hline
\end{tabular}


Table 6. Biological information from dens where only pups were removed, 1980 and 1981.

\begin{tabular}{|c|c|c|c|c|c|c|c|c|}
\hline Trial & Date & Iopography & $\begin{array}{c}\text { Distance } \\
(\mathrm{km})\end{array}$ & Animal Remains & No. Pups & $\begin{array}{l}\text { Est. } \\
\text { Age }\end{array}$ & Exposure & Notes \\
\hline 401 & $5-04-80$ & rocky slope & 1.6 & $-\quad-$ & 5 & 14 & E & 1:2 jackrabbit \\
\hline 402 & $5-06-80$ & rocky slope & 1.6 & *antelope carcass & 5 & 35 & $\mathrm{~s}$ & f crippled \\
\hline 403 & $6-16-80$ & tall sage draw & 1.6 & jackrabbit leg & 6 & 35 & E & large $\sigma^{2}(?)$ crippled \\
\hline 404 & $4-18-81$ & cutbank wash & 4.8 & sage grouse feather & 6 & 2 & $\therefore$ & $f$ in nole \\
\hline 405 & $4-26-81$ & rolling sage hills & 4.8 & lamb legsijaw & 8 & 14 & E & \\
\hline 406 & $5-05-81$ & rocky drai & 3.2 & $-\cdot-$ & 6 & $2 \varepsilon$ & $\therefore$ & $f$ in hole \\
\hline$\therefore 07$ & $5-06-31$ & rocky draw & 1.6 & $-\cdot-$ & 4 & 7 & $: \because$ & \\
\hline 408 & $5-10-81$ & rocky hill & 3.2 & sage grouse feathers & 7 & 21 & $\because$ & \\
\hline 409 & $5-18-81$ & rolling sage hills & 4.8 & $-\cdot-$ & 6 & 21 & - & \\
\hline 410 & $5-23-81$ & rocky draw & 3.2 & $-\cdot-$ & 7 & 28 & 6 & \\
\hline 411 & $5-31-81$ & rocky slope & 1.6 & $\begin{array}{l}\text { flicker feathers, } \\
\text { * sheep bone }\end{array}$ & 5 & 42 & "1 & \\
\hline 412 & $6-01-81$ & rolling sage hills & 3.2 & $-\cdot-$ & 6 & 14 & ' & no nole \\
\hline 413 & $6-05-81$ & rocky draw & 1.6 & lamb legs & 8 & 14 & is & \\
\hline 414 & $6-08-31$ & rocky slope & 6.4 & magpie feathers & 7 & 42 & $s$ & \\
\hline 415 & $6-18-81$ & tall sage draw & 6.4 & jacloabbit leg, lamb & 7 & 89 & E & \\
\hline
\end{tabular}


Table 7. Biological information from offending adult coyotes, 1980 and 1981.




Table 8. Numbers of lambs killed and percent consumed by coyotes, 1980 and 1981.

Percent

Consumed

0

33

67

90
Number

of lambs

$$
76^{a}
$$

$166^{b}$

72

31

\section{Percent \\ of total}

22

$70 \%$ consumed $1 / 3$ orless

48

$21\} 91 \%$

9

a - includes 4 ewes

b - includes 2 ewes 